\title{
A Global Analysis of Temperature Effects on Populus Plantation Production Potential
}

\author{
Natalya K. Kutsokon',2, Shibu Jose1, Eric Holzmueller ${ }^{3}$ \\ ${ }^{1}$ The Center for Agroforestry, University of Missouri, Columbia, MO, USA \\ ${ }^{2}$ Institute of Cell Biology and Genetic Engineering NAS of Ukraine, Kiev, Ukraine \\ ${ }^{3}$ Department of Forestry, Southern Illinois University, Carbondale, IL, USA \\ Email:kutsokon@nas.gov.ua, joses@missouri.edu, eholzmue@siu.edu
}

Received 4 November 2014; revised 20 November 2014; accepted 2 December 2014

Copyright (C) 2015 by authors and Scientific Research Publishing Inc.

This work is licensed under the Creative Commons Attribution International License (CC BY).

http://creativecommons.org/licenses/by/4.0/

(c) (i) Open Access

\section{Abstract}

The genus Populus contains some of the most economically important tree species and hybrids in the world. We compared productivity of short and long-rotation poplar plantations using published data from 23 countries to determine if climate, particularly temperature, had any effect on the observed patterns of productivity. We discovered that climate factors (related to temperature) and clone origin (pure species or hybrids) slightly influenced productivity of long rotation forests more than short rotation plantations. While long rotation plantation productivity exhibited positive correlations with increasing temperature during winter and decreasing heat during summer, short rotation plantations showed weak positive relationship among productivity and increasing yearly temperature and the number of hot days. It was apparent that short rotation plantations productivity was less dependent on regional climatic variables or origin of clone. However, it appears that overall, regardless of the system, Populus species are generally adapted to a range of climatic conditions where they are planted.

\section{Keywords}

Poplar, Populus sp., Hybrids, Fast-Growing Plantations, Intensive Forestry, Short and Long Rotation Plantations, Stem Volume, Climate

\section{Introduction}

The genus Populus is one of the most economically important woody plant genera in many parts of the world. Providing approximately 20 million $\mathrm{m}^{3}$ of wood and fiber annually, Populus spp. are desirable because of their fast growth and versatile use of the wood. In addition to the many products from the wood, Populus spp. also 
provide many important environmental functions such as the rehabilitation of degraded lands, protection of soils and water, conservation of biological diversity, providing shelter and shade, and sequestering carbon in temperate and subtropical regions of the world [1].

Populus is a genus native to the Northern hemisphere, most commonly growing in mixed forests in North America and Eurasia. Globally, most (91\%) of poplars are found in natural forests [2], however, planted forests represent a small, but rapidly expanding component, of poplar forests. There are nearly 5 million ha of poplar plantations worldwide and another 1.5 million ha in agroforestry systems. Most of these plantations (73\% of global total) are planted in China [1] and the most commonly planted poplars in the world are Populus $\times$ euramericana and $P$. deltoides cultivars.

In the United States, the first reported poplar artificial regeneration program began in 1893 when the Willamette Pulp and Paper Company planted 400 hectares of P. trichocarpa in the Oregon [3]. Additional plantations were soon established elsewhere in the region and due to the success of these initial plantings, the forest industry has looked to poplar production as one way to satisfy a continuously increasing demand for woody fiber.

Poplars are globally cultivated typically using two primary strategies: short rotation coppices (SRC) with very dense planting and short harvest rotation, 2 - 5 years, and long rotation plantations (LRP) with a wider initial spacing and longer rotation, generally 15 - 30 years. The main purpose of planting trees in SRC is generally production of biofuel wood or pulp, frequently used for pelleting or chopping, whereas in LRP production industrial roundwood is the main goal. Thus, those schemes are determined by the final products and cost-effectiveness [4]. Differences in sensitivity to biotic and abiotic stressors may also be a factor in making decisions on rotation length.

One of the most desirable characteristics of poplars is their fast growth. In the United States, individual studies indicate a wide range of production rates from 5.4 to $30 \mathrm{Mg} / \mathrm{ha} / \mathrm{yr}$ and results are dependent on a number of factors [5]-[8]. In terms of biomass production, Holzmueller and Jose [9] reported these values were comparable to the production of annual grain-based crops such as maize (7 - $9.7 \mathrm{Mg} / \mathrm{ha} / \mathrm{yr})$ and sorghum (4.5 Mg/ha/yr) [10] [11]. Such fast growth, however, is linked to short life span, with some Populus species reaching maturity at the age of 40 - 50 years.

The other primary reason Populus is so desirable for plantation production is that it is a very adaptable tree genus. It includes many species and hybrids that are able to grow under various conditions and have a wide spectrum of adaptations to biotic and abiotic stressors [12]. For example, De Woody et al. [13] demonstrated that Populus nigra leaf size was reduced and branching architecture changed across a north-south gradient in Europe. Villar et al. [14] suggest that some poplar species have genetic and ecophysiological characteristics to cope with the ongoing climate change that may allow us to use them successfully in the future.

The huge diversity of species, clones and hybrids, and the easy ability for interspecies hybridization for some species may be of great significance for adaptations. It has been suggested that crosses between European, American and Asian poplars, some of which occur naturally, are more tolerant to biotic and abiotic stressors, have better growth and productivity, and competitive ability. In a study of poplar hybrids in the western United States Stettler et al. [15] attributed these characteristics primarily to heterosis effects. In another example, crosses between European and American poplars showed superior performance in germination, survival rate, and shoot growth under elevated temperature, suggesting they may be more beneficial than pure species for plantation purposes [16]. It is possible that further performance increases may be achieved through genetic engineering [17]-[22]. However, the easiness of spontaneous hybridization between introduced and wild relatives may pose risks to the genetic integrity of native species and should bring some caution before introduction [23].

While poplar species are planted across the globe, there has been little analysis to compare production rates among plantations in different regions. Given the range of temperature within which poplars are planted and the different types of plantings, the objective of this study was to analyze patterns in productivity across a temperature gradient of two different types of Populus plantings, short rotation coppices (SRC) and long rotation plantations (LRP) for both pure species and hybrids.

\section{Materials and Methods}

Approximately 50 papers from 23 countries (North America, Eurasia, Australia) with more than 500 records (for short and long rotation plantations) were analyzed. While the list was not exhaustive we included as many studies from different regions and from different countries as possible. Only papers with available data about di- 
ameter and stem height at a given age, clearly described Populus species used, and type of plantation, SRC or LRP, were included. When possible, data about DBH were taken, but in a few studies, especially related to 1 year old SRC, only data on diameter at ground level were available. Annual stem volume indexes (SVI) were calculated based on DBH, height and age of trees by the formula: SVI $=\left(\mathrm{DBH}^{2} *\right.$ height $) /$ age. Correlation analysis was applied for estimation of productivity for pure species and hybrids in two different systems of planting, SRC and LRP. Comparisons in the differences between regression lines were determined with the use of $t$-criteria $(P<0.01)[24]$.

As data about temperature conditions were presented in a small amount of publications, we collected parameters by obtaining them from an open-source database (http://www.weatherbase.com). Parameters were chosen based on importance for plant vegetation as well as accessibility from base data for most localities. Those parameters were: average annual temperature, average annual high temperature, average annual low temperature, highest recorded annual temperature, lowest recorded annual temperature, average number of days above $32^{\circ} \mathrm{C}$, average number of days above $0^{\circ} \mathrm{C}$. If the place signed in paper was not present in the base data, closest geographical place were chosen. Pearson correlation tests were used to quantify relationships between stem volume indexes and temperature data, relationships were accepted statistically significant under the level of $P<0.01$.

Data about local soil conditions were included in our database but unfortunately were not used for analysis due to difficulties related to the wide range of soil classification. Data about irrigation, fertilization, chemicals used, altitude, longitude and elevation were not available in most publications, and therefore weren't applicable for analysis either.

\section{Results}

Ten different Populus species and 21 hybrids were used for analysis (Table 1). Both Populus spp. and hybrids were planted in LRP and SRC. Most plantations were established using either 15 - $30 \mathrm{~cm}$ length dormant hardwood cuttings (SRC and LRP) or 1-year-old rooted cuttings (preferably LRP). Spacing generally ranged from $0.5 \times 0.5 \mathrm{~m}$ to $1.5 \times 1.5 \mathrm{~m}$ for SRC and $2 \times 2 \mathrm{~m}$ to $6 \times 6 \mathrm{~m}$ for LRP. Calculated by stem volume index the average annual productivity per tree was $0.074 \mathrm{~m}^{3} / \mathrm{yr}$ for LRP and $0.005 \mathrm{~m}^{3} / \mathrm{yr}$ for SRC.

Comparison of growth parameters (DBH and height) for species and hybrids demonstrated that in LRP, hybrids are generally more productive than pure species, and the linear slope coefficient for hybrids was more than two times greater than those for non-hybrid Populus species (Figure 1). Tree height and DBH differences between slopes of regression lines were highly significant $(t=10.80, t=11.24$, respectively, $P<0.01)$. For SRC, tree height and DBH differences for hybrid and non-hybrid poplars were smaller and didn't differ significantly ( $t$ $=1.84$ for DBH, $t=0.03$ for tree height, $P>0.05$; Figure 2).

Results of statistical analysis for estimation of the effects of temperature parameters on poplar tree productivity did not show any strong correlations, but there were some significantly weak correlations (within $0.20<r<$ $0.32, P<0.01$ ) (Table 2). For LRP, wood productivity slowly increased with increasing lowest recorded annual temperature and the numbers of days above $0^{\circ} \mathrm{C}$ per year and decreased with increasing number of hot days above $32^{\circ} \mathrm{C}$. For SRC both average annual high temperatures and the number of hot days above $32^{\circ} \mathrm{C}$ have significant weak positive influence on SVI (Table 2).

\section{Discussion}

Hybrid poplars are typically selected for high productivity and it is not surprising that on average hybrid poplars outperformed pure species planted as LRP. We expected to see similar results in SRC, but this was not the case. However if you were to compare the size of the best hybrids to the best species in SRC, the hybrids showed better growth (Figure 1 and Figure 2). Decreased mean size in the SRC hybrids could be the result of the testing of experimental hybrids that would not typically be planted on a wide spread basis.

The lack of a strong relationship between temperature parameters and poplar growth could be explained by several factors. The first could be that while data from over 23 countries were analyzed, most of these plantations were in temperate environments, and the range in temperature parameters used in the analysis was not wide enough. In addition, poplar species are adapted to a wide range of conditions and commonly have extensive ranges. For example, the range of Populus deltoides (eastern cottonwood) extends from the southernmost United States to northern Canada. Therefore, given the wide latitude in which poplar species are naturally found differences in temperature may not influence poplar growth in most instances. 
Table 1. Populus species analyzed in current research (listed by countries).

\begin{tabular}{|c|c|c|c|}
\hline Populus sp. & Plantation & Country & Source \\
\hline P. deltoides, $P . \times$ euroamericana & LRP & Australia & [25] \\
\hline $\begin{array}{l}\text { P. balsamifera } \times P . \text { deltoides, } P . \text { balsamifera } \times P . \text { maximowiczii, } P . \text { balsamifera } \times \\
P . \text { trichocarpa, } P . \text { deltoides } \times P . \times \text { petrowskyana, } P . \times \text { euroamericana, } P . \text { maximowiczii } \\
\times P . \text { nigra, } P . \text { maximowiczii } \times P . \text { trichocarpa }\end{array}$ & LRP, SRC & Canada & {$[26]-[29]$} \\
\hline $\begin{array}{l}P . \text { deltoides, } P . \times \text { euroamericana } \times P . \text { nigra, } P . \times \text { interamericana, } P . \text { nigra } \times \\
P . \text { trichocarpa, } P . \text { tomentosa, } P . \text { tomentosa hybrids }\end{array}$ & LRP, SRC & China & {$[30]-[33]$} \\
\hline$P$. angulata, $P$. deltoides, $P$. nigra, $P . \times$ euroamericana, $P$. maximowiczii $\times P$. trichocarpa & LRP, SRC & Czech Republic & [34] [35] \\
\hline P. tremula, $P$. tremula $\times$ P. tremuloides & LRP & Finland & [36] [37] \\
\hline P. $\times$ euroamericana, $P . \times$ interamericana & SRC & France & [38] \\
\hline $\begin{array}{l}\text { P. trichocarpa, } P \times \text { interamericana, } P . \text { maximowiczii } \times P . \text { nigra, } P . \text { maximowiczii } \times \\
\text { P. trichocarpa }\end{array}$ & SRC & Germany & [39] \\
\hline P. $\times$ euroamericana & SRC & Greece & [40] \\
\hline $\begin{array}{l}P . \text { alba, } P \text {. deltoides, } P . \text { alba } \times P \text {. grandidentata, } P \text {. deltoides } \times P . \times \text { euroamericana, } P \text {. } \\
\times \text { interamericana }\end{array}$ & LRP & Hungary & {$[41]-[43]$} \\
\hline P. deltoides & LRP & India & [44]-[48] \\
\hline P. deltoides & LRP & Iran & [49] \\
\hline$P$. deltoides $\times P . \times$ euroamericana, $P . \times$ euroamericana, $P . \times$ generosa $\times P$. nigra & SRC & Italy & {$[50]$} \\
\hline P. maximowiczii & SRC & Japan & {$[51]$} \\
\hline P. $\times$ euroamericana & LRP & New Zealand & {$[52]$} \\
\hline$P$. alba, $P$. deltoides, $P$. nigra, $P$. trichocarpa, $P . \times$ euroamericana, $P . \times$ interamericana & LRP, SRC & Romania & [53] \\
\hline P. balsamifera, $P$. tremula, $P$. tremuloides, $P . \times$ euroamericana & LRP & Russia & [54]-[56] \\
\hline$P$. deltoides, $P$.deltoides $\times P . \times$ euroamericana, $P . \times$ euroamericana & LRP, SRC & Serbia & [57]-[59] \\
\hline $\begin{array}{l}P . \text { nigra, } P . \text { angulata } \times P . \text { nigra, } P . \text { deltoides, } P . \times \text { euroamericana, } P . \times \text { interamericana, } \\
P . \text { maximowiczii } \times P . \text { nigra }\end{array}$ & LRP & Slovak Republic & [4] [60] \\
\hline$P . \times$ euroamericana, $P . \times$ interamericana, $P . \times$ interamericana $\times P$. nigra & $\mathrm{SRC}$ & Spain & [61] \\
\hline $\begin{array}{l}P . \text { balsamifera, } P \text {. trichocarpa, } P . \times \text { interamericana, } P . \text { maximowiszii } \times P \text { trichocarpa, } \\
P . \text { deltoides } \times P \text {. maximowiczii, } P . \text { tremula } \times P \text {. tremuloides }\end{array}$ & LRP & Sweden & [62] [63] \\
\hline$P$. deltoides, $P$. alba $\times P$. deltoides, $P . \times$ euroamericana & LRP & Turkey & [64] [65] \\
\hline P. nigra, $P$. balsamifera $\times$ P.trichocarpa, $P . \times$ euroamericana, $P$. laurifolia $\times P$. nigra & LRP, SRC & Ukraine & [66] [67] \\
\hline $\begin{array}{l}P . \text { deltoides, } P . \text { nigra, } P . \text { trichocarpa, } P . \text { balsamifera } \times(P . \text { laurifolia } \times P . \text { nigra }), P \text {. } \\
\text { deltoides } \times P . \text { maximowiczii, } P . \times \text { euroamericana, } P . \times \text { interamericana, } P . \text { maximowiczii } \\
\times P . \text { nigra, } P . \text { nigra } \times P \text {. trichocarpa }\end{array}$ & LRP, SRC & USA & [68]-[73] \\
\hline
\end{tabular}

Table 2. Pearson's correlation coefficients relationships between yearly stem volume indexes (SVI) and temperature data.

\begin{tabular}{|c|c|c|c|c|}
\hline Climate data & $\begin{array}{c}\text { Range for long rotation } \\
\text { plantations }\end{array}$ & $\begin{array}{l}\text { Range for short } \\
\text { rotation plantations }\end{array}$ & $\begin{array}{c}r \text { (SVI), long rotation } \\
\text { plantations }\end{array}$ & $\begin{array}{c}r(\mathrm{SVI}) . \text { short } \\
\text { rotation plantations }\end{array}$ \\
\hline Average annual temperature & 1.2 to $18.0^{\circ} \mathrm{C}$ & 1.2 to $15.1^{\circ} \mathrm{C}$ & $0.155^{*}$ & 0.109 \\
\hline Average annual high temperature & 6.0 to $24.0^{\circ} \mathrm{C}$ & 7.0 to $20.3^{\circ} \mathrm{C}$ & 0.113 & $\underline{0.273^{*}}$ \\
\hline Average annual low temperature & -4.7 to $13.0^{\circ} \mathrm{C}$ & -4.7 to $11.0^{\circ} \mathrm{C}$ & $0.167 *$ & -0.062 \\
\hline Highest recorded annual temperature & 28.0 to $45.4^{\circ} \mathrm{C}$ & 33.0 to $43.2^{\circ} \mathrm{C}$ & -0.060 & -0.027 \\
\hline Lowest recorded annual temperature & -48.3 to $-3.9^{\circ} \mathrm{C}$ & -43.9 to $-6.0^{\circ} \mathrm{C}$ & $\underline{0.206^{*}}$ & 0.189 \\
\hline Average number of days above $32^{\circ} \mathrm{C}$ per year & 0 to 90 & 0 to 63 & $-0.228^{*}$ & $\underline{0.314^{*}}$ \\
\hline Average number of days above $0^{\circ} \mathrm{C}$ per year & 158 to 362 & 158 to 343 & $\underline{0.300^{*}}$ & 0.058 \\
\hline
\end{tabular}

*correlation is significant under $P<0.01$; weak correlations (within $0.20<r<0.32$ ) are underlined. 


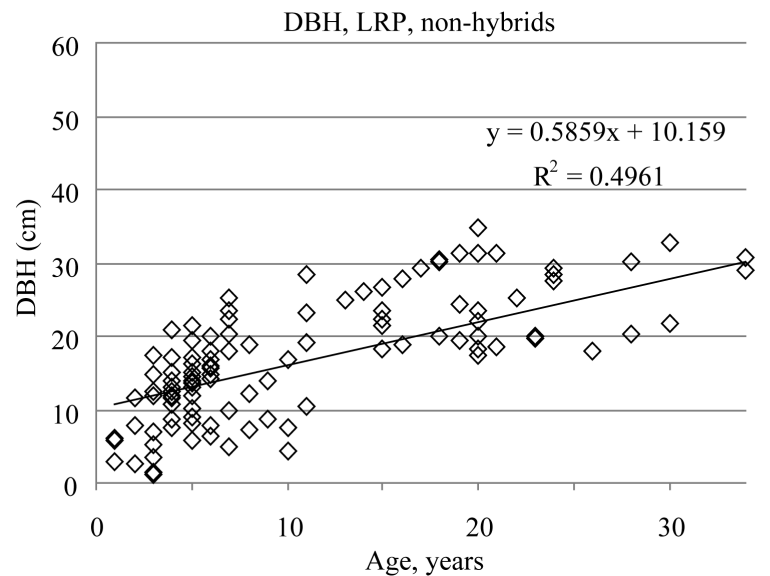

(a)

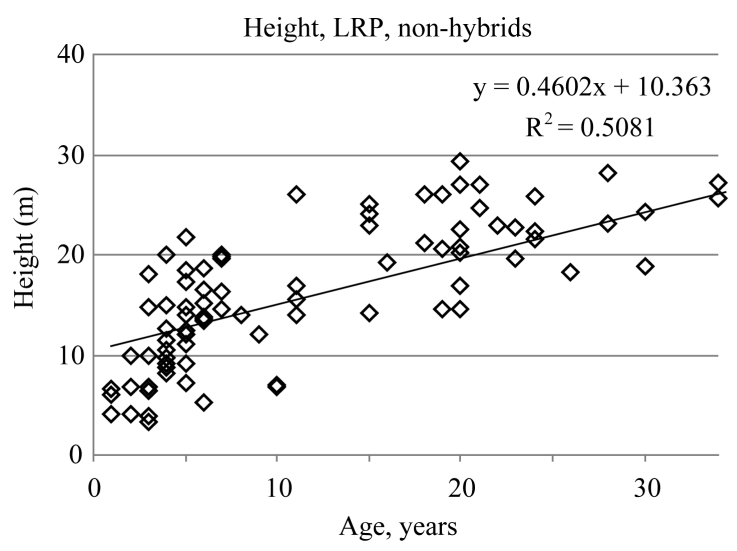

(c)

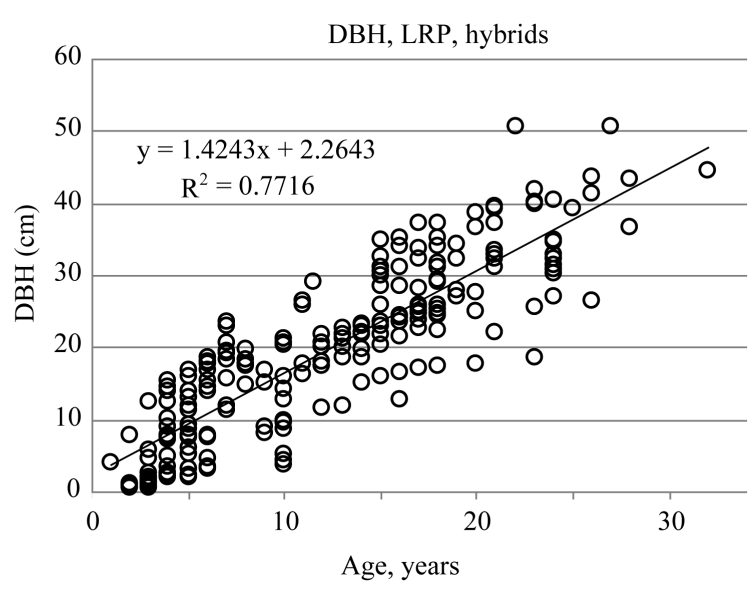

(b)

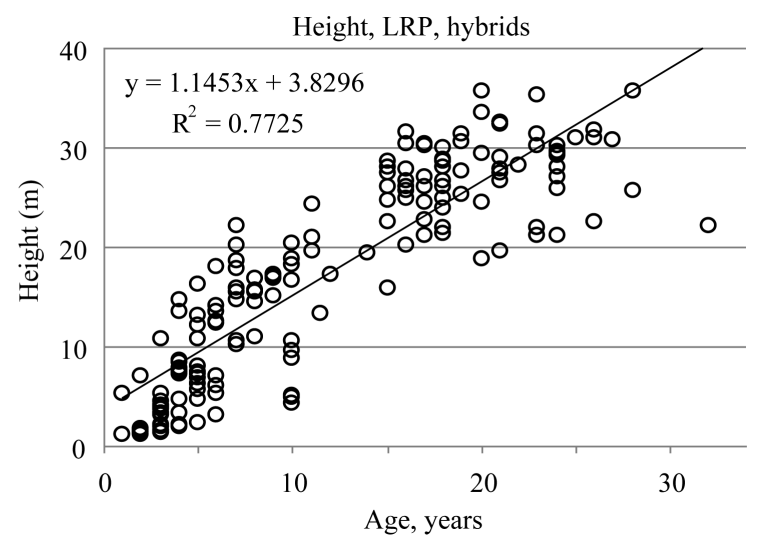

(d)

Figure 1. Age dynamics of DBH (a) (b) and height (c) (d) in long rotation plantations (LRP) for non-hybrid (a) (c) and hybrid (b) (d) poplar trees.

However, when analyzing productivity and temperature conditions, an interesting phenomenon was discovered. Indian plantations demonstrated sharp divergence from normal distributions and generally have higher productivity by stem volume indexes than plantations in other countries. We speculated that this effect was due to year-round favorable weather conditions as this was the only region that had zero days with temperature below $0^{\circ} \mathrm{C}$. Therefore, trees could grow without (or very short) dormant periods. From the first look it was unexpected as there was a weak negative relationship between poplar growth and number of hot days above $32^{\circ} \mathrm{C}$. But probably year-round favorable weather gives more benefits for poplar growth. Additional studies of poplars in warmer environments are needed to further test this hypothesis.

Other studies have suggested that water availability plays a larger role than temperature in poplar productivity [74]. Poplars are susceptible to drought and are commonly found in riparian regions, particularly in more arid environments. Jules et al. [75] observed that higher precipitation and cooler summers were positively correlated with plant growth. Conversely, some studies indicated that on a regional level, temperature can override the influence of precipitation levels. In a study of Populus tremuloides in British Columbia, positive correlations between tree height growth and mean annual temperature and mean annual summer temperature were observed, but no correlations were found for precipitation. Authors suggested that in this study growing season temperature was more limited than water availability [76].

In our study, LRP demonstrated some correlation between productivity and increasing temperature during winter and decreasing heat during summer; and for SRC, weak positive correlations between productivity and increasing yearly temperature and the number of hot days. Those findings may be partially based on the differences in range of parameters. While number of days above $32^{\circ} \mathrm{C}$ for LRP ranged 0 to 90 days, for SRC it ranged 


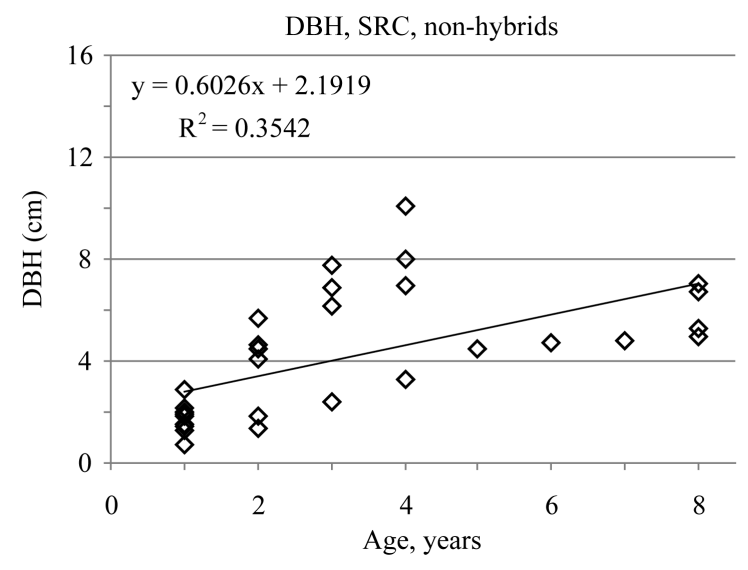

(a)

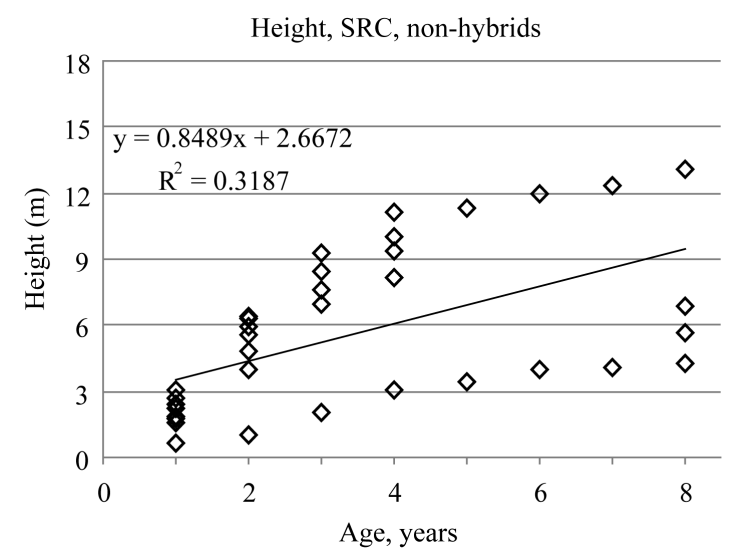

(c)

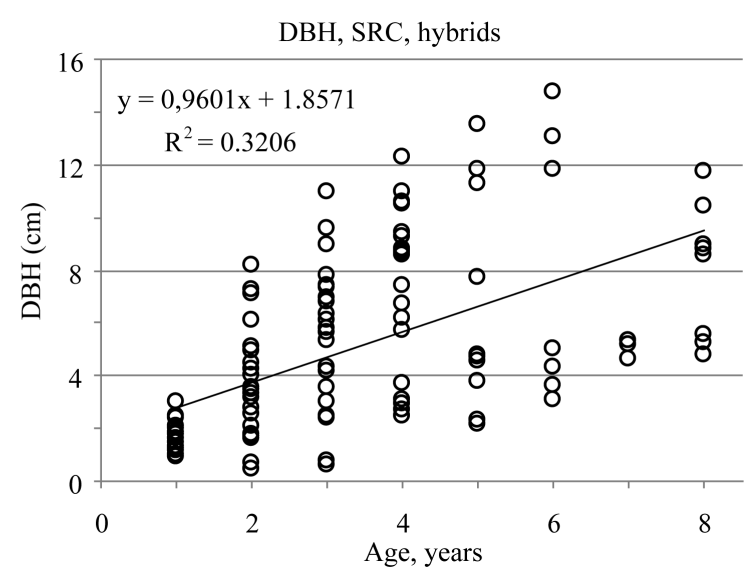

(b)

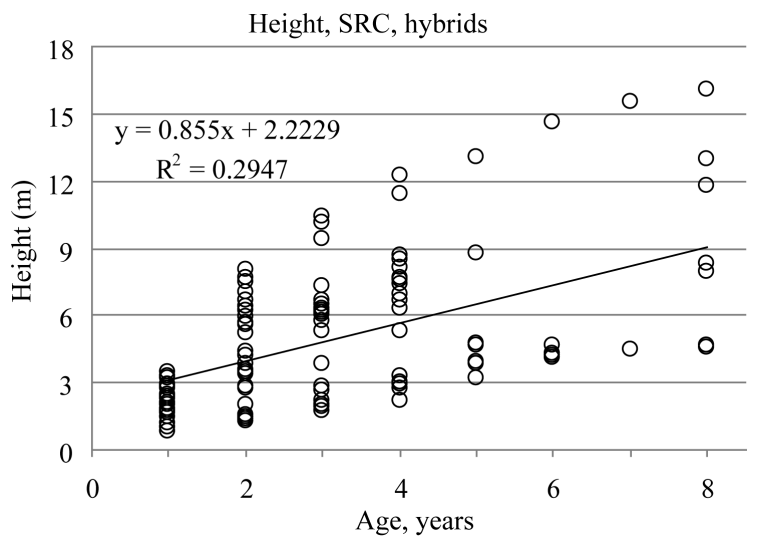

(d)

Figure 2. Age dynamics of DBH (a) (b) and height (c) (d) in short rotation coppices (SRC) for non-hybrid (a) (c) and hybrid (b) (d) poplar trees.

between 0 to 63 days (Table 2). We surmise that while too many hot days may be a limiting factor, it is probably reached after some critical threshold.

Climate parameters based on temperature, demonstrate that woody biomass production is possible under wide range of optimal temperature conditions. The number of hot summer days appears to decrease productivity in LRP; however, this may be offset by increased winter temperatures in these climates. High productivity for poplar plantations may be reached by using a broad genetic diversity of poplars and utilizing the highly adaptive potential of this genus. Overall, we observed an occurrence of a genotypic variability for productivity and some degree of sensitivity to environmental change in Populus, particularly for LRP. It is obvious that there is a wide range of adaptability for this genus, which is helpful to maintaining high levels of productivity even under predicted changes in future climate [75] [77]-[82].

\section{Conclusion}

We found that climate factors (related to temperature) and clone origin (pure species or hybrids) generally influenced production potential in long rotation plantations, but not in short rotation plantations. Opposite effects of number of hot days per year on LRP and SRC demonstrated that producing of wood in LRP was more vulnerable to the number of excessive heat days and an increase in number of excessive hot days. Our findings reveal that well managed SRC poplar plantations may have wider applications for regions with extreme temperature conditions, to which long rotation forests are more sensitive. It is most likely connected with more intensive early growth of poplar trees and may be offset with more active management of SRC, e.g. irrigation and fertilization. We conclude that SRC plantations appear to be less sensitive to environmental conditions than LRP ir- 
respective of the geographic location. Overall, our analysis clearly indicates that growing Populus in SRC systems with proper cultural practices can decouple the effects of climate change on productivity.

\section{Acknowledgements}

This work was supported by the J. William Fulbright Foreign Scholarship Board and the Bureau of Educational and Cultural Affairs of the United States Department of State through a Fulbright Scholar Grant for 2012-2013 to Dr. N.K. Kutsokon, who is very thankful for the great opportunity to carry out the research.

\section{References}

[1] FAO (2005) International Poplar Commission Report of the 22nd Session of the Commission and of the 42nd Session of its Executive Committee. http://www.fao.org/forestry/9497-0be6293ee294ca6ff64cd8f5f570e1c1b.pdf

[2] Singh, A. and Kumar, A. (2012) Poplars and Willows for Increasing the Livelihood and Rural Development: A Review. Report on International Poplar Commission 24th Session, Dehradun, 29 October-2 November 2012, 155.

[3] Berguson, B., Eaton, J. and Stanton, B. (2010) Development of Hybrid Poplar for Commercial Production in the United States: The Pacific Northwest and Minnesota Experience. In: Braun, R., Karlen, D. and Johnson E., Eds., Sustainable Alternative Fuel Feedstock Opportunities, Challenges and Roadmaps for Six U.S. Regions, 282-299.

[4] Bartko, M. (2011) Analyza Biologickych, Produkcnych a Ekonomickych Aspektov Pestovania Rychlorastucich Drevin na Sovensku. Ph.D. Thesis, LF TU, Zvolen.

[5] Geyer, W.A. (2006) Biomass Production in the Central Great Plains USA under Various Coppice Regimes. Biomass and Bioenergy, 30, 778-783. http://dx.doi.org/10.1016/j.biombioe.2005.08.002

[6] Goerndt, M.E. and Mize, C.W. (2008) Short-Rotation Woody Biomass as a Crop on Marginal Lands in Iowa. Northern Journal of Applied Forestry, 25, 82-86.

[7] Riemenschneider, D.E., Berguson, W.E., Dickmann, D.I., Hall, R.B., Isebrands, J.G., Mohn, C.A., Stanosz, G.R. and Tuskan, G.A. (2001) Poplar Breeding and Testing Strategies in the North-Central U.S.: Demonstration of Potential Yield and Consideration of Future Research Needs. Forestry Chronicle, 77, 245-253. http://dx.doi.org/10.5558/tfc77245-2

[8] Tufekcioglu, A., Raich, J.W., Isenhart, T.M. and Schultz, R.C. (2003) Biomass, Carbon, and Nitrogen Dynamics of Multi-Species Riparian Buffers within an Agricultural Watershed in Iowa, USA. Agroforestry Systems, 57, 187-198. http://dx.doi.org/10.1023/A:1024898615284

[9] Holzmueller, E.J. and Jose, S. (2012) Biomass Production for Biofuels Using Agroforestry: Potential for the North Central Region of the United States. Agroforestry Systems, 85, 305-314. http://dx.doi.org/10.1007/s10457-012-9502-z

[10] Tollenaar, M. and Lee, E.A. (2002) Yield Potential, Yield Stability and Stress Tolerance in Maize. Field Crops Research, 75, 161-169. http://dx.doi.org/10.1016/S0378-4290(02)00024-2

[11] USDA (U.S. Department of Agriculture) (2010) National Agricultural Statistics Service. http://www.nass.usda.gov/

[12] Yaqoob, N., Karlsson, J., Riber, B.A., Solheim, H. and Fossdal, C.G. (2010) Constitutive and Induced Resistance between a Susceptible and Resistant Aspen Clone and Transcriptional Difference Towards Melampsora megnosiana. 5th International Poplar Symposium: Poplars and Willows: From Research Models to Multipurpose Trees for a Bio-Based Society, Orvieto, 20-25 September 2010, 204.

[13] DeWoody, J., Trewin, H., Viger, M. and Taylor, G. (2010) Growing Large Leaves from a Small-Leaf Gene Pool: Evolutionary Trajectories in Populus nigra L. (Black Poplar) in Context of a Changing Climate. 5th International Poplar Symposium: Poplars and Willows: From Research Models to Multipurpose Trees for a Bio-Based Society, Orvieto, 20-25 September 2010, 19.

[14] Villar, M., Chamaillard, S., Barbaroux, C., Bastien, C., Brignolas, F., Faivre Rampant, P., Fichot, R., Forestier, O., Jorge, V. and Rodrigues, S. (2010) Populus nigra as Keystone Species Able to Cope with the Ongoing Climate Change. 5th International Poplar Symposium: Poplars and Willows: From Research Models to Multipurpose Trees for a BioBased Society, Orvieto, 20-25 September 2010, 17.

[15] Stettler, R.F., Fenn, R.C., Heilman, P.E. and Stanton, B.J. (1988) Populus trichocarpa $\times$ Populus deltoides Hybrids for Short Rotation Culture: Variation Patterns and 4-Year Field Performance. Canadian Journal of Forest Research, 18, 745-753. http://dx.doi.org/10.1139/x88-114

[16] Pulkkinen, P., Vaario, L.M., Koivuranta, L. and Stenvall, N. (2013) Elevated Temperature Effects on Germination and Early Growth of European Aspen (Populus tremula), Hybrid Aspen (P. tremula $\times$ P. tremuloides) and Their $\mathrm{F}_{2}-\mathrm{Hybrids}_{\text {. }}$ European Journal of Forest Research, 132, 791-800. http://dx.doi.org/10.1007/s10342-013-0719-9

[17] Confalonieri, M., Balestrazzi, A., Bisoffi, S. and Carbonera, D. (2003) In Vitro Culture and Genetic Engineering of 
Populus spp.: Forest Tree Improvement. Plant Cell, Tissue and Organ Culture, 72, 109-138. http://dx.doi.org/10.1023/A:1022265504775

[18] Giri, C.C., Shyamkumar, B. and Anjaneyulu, C. (2004) Progress in Tissue Culture, Genetic Transformation and Applications of Biotechnology to Trees: An Overview. Trees, 18, 115-135. http://dx.doi.org/10.1007/s00468-003-0287-6

[19] Han, K.H., Meilan, R., Ma, C. and Strauss, S.H. (2000) An Agrobacterium tumefaciens Transformation Protocol Effective on a Variety of Cottonwood Hybrids (Genus Populus). Plant Cell Reports, 19, 315-320. http://dx.doi.org/10.1007/s002990050019

[20] Herschbach, C. and Kopriva, S. (2002) Transgenic Trees as Tools in Tree and Plant Physiology. Trees, 16, $250-261$. http://dx.doi.org/10.1007/s00468-002-0178-2

[21] Kutsokon, N.K. (2011) Main Trends in the Genetic Transformation of Populus Species. Cytology and Genetics, 45, 352-361. http://dx.doi.org/10.3103/S009545271106003X

[22] Yevtushenko, D.P. and Misra, S. (2010) Efficient Agrobacterium-Mediated Transformation of Commercial Hybrid Poplar Populus nigra L. × P. maximowiczii A. Henry. Plant Cell Reports, 29, 211-221. http://dx.doi.org/10.1007/s00299-009-0806-z

[23] Isabel, N., Talbot, P., Lamothe, M., Bousquet, J., Schroeder, W., Floate, K., Foottit, R.G., Ruiz, P., Cumming, S., McIntire, E. and Thompson, S.L. (2010) Contemporary Gene Flow between Poplars with Exotic Component and Natural Populations of Native Species across Canada. 5th International Poplar Symposium: Poplars and Willows: From Research Models to Multipurpose Trees for a Bio-Based Society, Orvieto, 20-25 September 2010, 21.

[24] Fowler, J. and Cohen, L. (1990) Practical Statistics for Field Biology. Milton Keynes, Philadelphia.

[25] Hopmans, P., Stewart, H.T.L., Flinn, D.W. and Hillman, T.J. (1990) Growth, Biomass Production and Nutrient Accumulation by Seven Tree Species Irrigated with Municipal Effluent at Wodonga, Australia. Forest Ecology and Management, 30, 203-211. http://dx.doi.org/10.1016/0378-1127(90)90137-Z

[26] Benomar, L., DesRochers, A. and Larocque, G.R. (2012) The Effects of Spacing on Growth, Morphology and Biomass Production and Allocation in Two Hybrid Poplar Clones Growing in the Boreal Region of Canada. Trees, 26, 939-949. http://dx.doi.org/10.1007/s00468-011-0671-6

[27] Brown, K.R. and van den Driessche, R. (2002) Growth and Nutrition of Hybrid Poplars over 3 Years after Fertilization at Planting. Canadian Journal of Forest Research, 32, 226-232. http://dx.doi.org/10.1139/x01-191

[28] Driessche, R., Thomas, B.R. and Kamelchuk, D.P. (2008) Effects of N, NP, and NPKS Fertilizers Applied to FourYear Old Hybrid Poplar Plantations. New Forests, 35, 221-233. http://dx.doi.org/10.1007/s11056-007-9073-4

[29] Labrecque, M. and Teodorescu, T.I. (2005) Field Performance and Biomass Production of 12 Willow and Poplar Clones in Short-Rotation Coppice in Southern Quebec (Canada). Biomass and Bioenergy, 29, 1-9. http://dx.doi.org/10.1016/j.biombioe.2004.12.004

[30] Fang, S., Xie, B., Liu, D. and Liu, J. (2011) Effects of Mulching Materials on Nitrogen Mineralization, Nitrogen Availability and Poplar Growth on Degraded Agricultural Soil. New Forests, 41, 147-162. http://dx.doi.org/10.1007/s11056-010-9217-9

[31] Fang, S., Xu, X., Lu, S. and Tang, L. (1999) Growth Dynamics and Biomass Production in Short-Rotation Poplar Plantations: 6-Year Results for Three Clones at Four Spacings. Biomass and Bioenergy, 17, 415-425. http://dx.doi.org/10.1016/S0961-9534(99)00060-4

[32] Guo, X.Y. and Zhang, X.S. (2010) Performance of 14 Hybrid Poplar Clones Grown in Beijing, China. Biomass and Bioenergy, 34, 906-911. http://dx.doi.org/10.1016/j.biombioe.2010.01.036

[33] Zhang, P., Wu, F. and Kang, X. (2012) Genotypic Variation in Wood Properties and Growth Traits of Triploid Hybrid Clones of Populus tomentosa at Three Clonal Trials. Tree Genetics \& Genomes, 8, 1041-1050. http://dx.doi.org/10.1007/s11295-012-0484-9

[34] Benetka, V., Vratny, V. and Salkova, I. (2007) Comparison of the Productivity of Populus nigra L. with an Interspecific Hybrid in a Short Rotation Coppice in Marginal Areas. Biomass and Bioenergy, 31, 367-374. http://dx.doi.org/10.1016/j.biombioe.2007.01.005

[35] Cizkova, L., Cizek, V. and Bajajova, H. (2010) Growth of Hybrid Poplars in Silviculture at the Age of 6 Years. Journal of Forest Science, 56, 451-460.

[36] Nikula, S., Manninen, S., Vapaavuori, E. and Pulkkinen, P. (2011) Growth, Leaf Traits and Litter Decomposition of Roadside Hybrid Aspen (Populus tremula L. × P. tremuloides Michx.) Clones. Environmental Pollution, 159, $1823-1831$. http://dx.doi.org/10.1016/j.envpol.2011.03.022

[37] Yu, Q. and Pulkkinen, P. (2003) Genotype-Environment Interaction and Stability in Growth of Aspen Hybrid Clones. Forest Ecology and Management, 173, 25-35. http://dx.doi.org/10.1016/S0378-1127(01)00819-2

[38] Benbrahim, M., Gavaland, A. and Gauvin, J. (2000) Growth and Yield of Mixed Polyclonal Stands of Populus in 
Short-Rotation Coppice. Scandinavian Journal of Forest Research, 15, 605-610. http://dx.doi.org/10.1080/02827580050216851

[39] Bungart, R. and Huttl, R.F. (2004) Growth Dynamics and Biomass Accumulation of 8-Year-Old Hybrid Poplar Clones in a Short-Rotation Plantation on a Clayey-Sandy Mining Substrate with Respect to Plant Nutrition and Water Budget. European Journal of Forest Research, 123, 105-115.

[40] Spanos, K., Tsialtas, I. and Giakzidis, G. (2002) Biomass Production from a Short Rotation Coppice Experimental Planting of Ten Poplars Clones in N. Greece Study, Conservation and Utilization of Forest Resources. Proceedings of the 3rd Balkan Scientific Conference, Sofia, 2-6 October 2001, 326-335.

[41] Barany, G. (2011) A Nemesnyar-Termesztes Fejlesztesenek Ujabb Eredmenyei. Ph.D. Thesis, Sopron, Budapest.

[42] Redei, K., Keseru, Z. and Szulcsan, G. (2010) Early Evaluation of Promising White Poplar (Populus alba L.) Clones in Hungary. Acta Silvatica \& Lingaria Hungarica, 6, 9-16.

[43] Redei, K. and Keseru, Z.S. (2008) Promising White Poplar (Populus alba L.) Clones in Sandy Ridges between the Rivers Danube and Tisza in Hungary. International Journal of Horticultural Science, 14, 113-116

[44] Chauhan, S.K., Brar, M.S. and Sharma, R. (2012) Performance of Poplar (Populus deltoides Bartr.) and Its Effect on Wheat Yield under Agroforestry System in Irrigated Agro-Ecosystem, India Caspian. Journal of Environmental Sciences, 10, 53-60.

[45] Dhillon, G.P.S., Singh, A.P. and Sidhu, D.S. (2010) Field Evaluation of Populus deltoids Bartr. ex Marsh. at Two Sites in Indo-Gangetic Plains of India. Silvae Genetica, 59, 1-7.

[46] Dhillon, G.P.S., Singh, A., Sidhu, D.S. and Brar, H.S. (2013) Variation among Poplar Clones for Growth and Crown Traits under Field Conditions at Two Sites of North-Western India. Journal of Forestry Research, 24, 61-67. http://dx.doi.org/10.1007/s11676-012-0269-x

[47] Puri, S., Swamy, S.L. and Jaiswal, A.K. (2002) Evaluation of Populus deltoides Clones under Nursery, Field and Agrisilviculture System in Subhumid Tropics of Central India. New Forests, 23, 45-61. http://dx.doi.org/10.1023/A:1015620915654

[48] Sidhu, D.S. and Dhillon, G.P.S. (2007) Field Performance of Ten Clones and Two Sizes of Planting Stock of Populus deltoides on the Indo-Gangetic Plains of India. New Forests, 34, 115-122. http://dx.doi.org/10.1007/s11056-007-9042-y

[49] Salehi, A. and Maleki, M. (2012) Evaluation of Soil Physical and Chemical Properties in Poplar Plantations in North of Iran. Ecologia Balkanica, 4, 69-76.

[50] Pannacci, E., Bartolini, S. and Covarelli, G. (2009) Evaluation of Four Poplar Clones in a Short Rotation Forestry in Central Italy. Italian Journal of Agronomy/Rivista di Agronomia, 4, 191-198.

[51] Osawa, A. (1993) Effects of Mechanical Stresses and Photosynthetic Production on Stem Form Development of Populus maximowiczii. Annals of Botany, 71, 489-494. http://dx.doi.org/10.1006/anbo.1993.1065

[52] McIvor, R., Douglas, G.B. and Benavides, R. (2009) Coarse Root Growth of Veronese Poplar Trees Varies with Position on an Erodible Slope in New Zealand. Agroforestry Systems, 76, 251-264. http://dx.doi.org/10.1007/s10457-009-9209-y

[53] Filat, M. and Chira, D. (2004) Cercetari Pentru Introducerea in Cultura de Specii/Clone de Plop si Salcie cu Potential Silvoproductiv Superior si Rezistenta Sporita la Adversitat. Analele ICAS, 47, 83-99.

[54] Sivolapov, V.A. (2012) Plantation Cultivation of Fast-Growing Species in the of Forest-Steppe Region with the Using in Vitro Biotechnology. Ph.D. Thesis, Voronezh.

[55] Tsarev, A.P. (2012) Fodder Value of Populus euramericana. Green Biomass Journal of Agricultural Science and Technology, 2, 498-509.

[56] Tsarev, V.A. and Tsarev, A.P. (2011) Breeding of Aspens in CCR. 6th Conference "Forests of Russia in 21st”, St. Peterburg, March 2011, 186-191.

[57] Andrasev, S., Roncevic, S. and Pekec, S. (2006) Karakteristike Rasta Nekih Klonova Crnih Topola (Growth Characteristics of Some Black Poplar Clones). Sumar inst Jastrebar, 41, 25-30.

[58] Klasnja, B., Orlovic, S. and Galic, Z. (2012) Energy Potential of Poplar Plantations in Two Spacings and Two Rotations. Sumarski List, 136, 161-167.

[59] Orlovic, S., Guzina, V., Krstic, B. and Merkulov, L. (1998) Genetic Variability in Anatomical, Physiological and Growth Characteristics of Hybrid Poplar (Populus $\times$ euramericana Dode (Guinier)) and Eastern Cottonwood (Populus deltoides Bartr.) Clones. Silvae Genetica, 47, 183-190.

[60] Kohan, S. (2006) Valuation on Growth and Volume Production and Health Evaluation of Poplar Clones on Alluvial Soils of Laborec River in Eastern Slovakian Lowland. Forestry Journal, 52, 239-247. 
[61] Sixto, H., Salvia, H., Barrio, M., Ciria, M.P. and Canellas, I. (2011) Genetic Variation and Genotype-Environment Interactions in Short Rotation Populus Plantations in Southern Europe. New Forests, 42, 163-177. http://dx.doi.org/10.1007/s11056-010-9244-6

[62] Christersson, L. (2010) Wood Production Potential in Poplar Plantations in Sweden. Biomass and Bioenergy, 34, 12891299. http://dx.doi.org/10.1016/j.biombioe.2010.03.021

[63] Johansson, T. and Karacic, A. (2011) Increment and Biomass in Hybrid Poplar and Some Practical Implications. Biomass and Bioenergy, 35, 1925-1934. http://dx.doi.org/10.1016/j.biombioe.2011.01.040

[64] Gurses, M.K., Tufekci, S., Gulbaba, A.G., Ozkurt, N. and Ozkurt, A. (1999) The Results of Comparison Populeta Established in the Mediterranean Region. Teknik Bulten Orman Bakanlg Dogu Akdeniz Ormanclk Arastrma Enstitusu, 10, $\mathrm{v}+16$.

[65] Gurses, M.K., Gulbaba, A.G., Avcioglu, E., Ozkurt, N., Ozkurt, A. and Tufekci, S. (1997) Dogu Akdenizve Guneydogu Anadolu Bulgeleri Oryantasyon Populetumlari Sonuclari. Dogu Akdeniz Ormancilik Arastirma Enstitusu, Teknik Bulten, Tarsus, 3, $18 \mathrm{p}$.

[66] Fuchylo, Y.D., Sbytna, M.V., Fuchylo, Y.O. and Litvin, V.M. (2009) Experience and Perspectives of Cultivation of Poplar (Populus sp. L.) in Southern Steppe Region of Ukraine. Scientific Works of Ukrainian Forestry Academy, 7, 66-69.

[67] Patlay, I.M. (Project Leader) (1991-1995) Breeding, Varieties Testing and Propagation of Important Native and Introduced Species of Forest Trees for Creation of Plantations for Different Purposes. Report of URIFFM Project No. 13.

[68] Ceulemans, R., Scarascia-Mugnozza, G., Wiard, B.M., Braatne, J.H., Hinckley, T.M., Stettler, R.F., Isebrands, J.G. and Heilman, P.E. (1992) Production Physiology and Morphology of Populus Species and Their Hybrids Grown under Short Rotation. I. Clonal Comparisons of 4-Year Growth and Phenology. Canadian Journal of Forest Research, 22, 1937-1948. http://dx.doi.org/10.1139/x92-253

[69] DeBell, D.S., Harrington, C.A., Clendenen, G.W. and Zasada, J.S. (1997) Tree Growth and Stand Development of Four Populus Clones in Large Monoclonal Plots. New Forests, 14, 1-18. http://dx.doi.org/10.1023/A:1006501229936

[70] Kaczmarek, D.J., Coyle, D.R. and Coleman, M.D. (2013) Survival and Growth of a Range of Populus Clones in Central South Carolina USA through Age Ten: Do Early Assessments Reflect Longer-Term Survival and Growth Trends? Biomass and Bioenergy, 49, 260-272. http://dx.doi.org/10.1016/j.biombioe.2012.12.005

[71] Netzer, D.A., Tolsted, D.N., Ostry, M.E., Isebrands, J.G., Riemenschneider, D.E. and Ward, K.T. (2002) Growth, Yield, and Disease Resistance of 7- to 12-Year-Old Poplar Clones in the North Central United States. Gen. Tech. Rep. NC-229, St. Paul.

[72] O’Neill, M.K., Shock, C.C., Lombard, K.A., Heyduck, R.F., Feibert, B.G., Smeal, D. and Arnold, R.N. (2010) Hybrid Poplar (Populus ssp.) Selections for Arid and Semi-Arid Intermountain Regions of the Western United States. Agroforestry Systems, 79, 409-418. http://dx.doi.org/10.1007/s10457-010-9286-y

[73] Pearson, C.H., Halvorson, A.D., Moench, R.D. and Hammon, R.W. (2010) Production of Hybrid Poplar under ShortTerm, Intensive Culture in Western Colorado. Industrial Crops and Products, 31, 492-498. http://dx.doi.org/10.1016/j.indcrop.2010.01.011

[74] Zsuffa, L., Giordano, E., Pryor, L.D. and Stettler, R.F. (1996). Trends in Poplar Culture: Some Global and Regional Perspectives. In: Stettler, R.F., Bradshaw Jr., H.D., Heilman, P.E. and Hinckley, T.M., Eds., Biology of Populus and Its Implications for Management and Conservation, Part II, Chapter 19, NRC Research Press, National Research Council of Canada, Ottawa, 515-539.

[75] Jules, E.K., Carroll, A.L. and Kauffman, M.J. (2010) Relationship of Climate and Growth of Quaking Aspen (Populus tremuloides) in Yellowstone National Park. Final Report for RWO 81 Rocky Mountain Ungulates.

[76] Messaoud, Y. and Chen, H.Y. (2011) The Influence of Recent Climate Change on Tree Height Growth Differs with Species and Spatial Environment. PLOS One, 16, 1-8.

[77] Chhin, S. (2010) Influence of Climate on the Growth of Hybrid Poplar in Michigan. Forests, 1, 209-229.

[78] Henderson, D.E. and Jose, S. (2010) Biomass Production Potential of Three Short Rotation Woody Crop Species under Varying Nitrogen and Water Availability. Agroforestry Systems, 80, 259-273. http://dx.doi.org/10.1007/s10457-010-9283-1

[79] Monclus, R., Villar, M., Barbaroux, C., Bastien, C., Fichot, R., Delmotte, F.M., Delay, D., Petit, J.M., Bruchet, C., Dreyer, E. and Brignolas, F. (2009) Productivity, Water-Use Efficiency and Tolerance to Moderate Water Deficit Correlate in 33 Poplar Genotypes from a Populus deltoids $\times$ Populus trichocarpa $\mathrm{F}_{1}$ Progeny. Tree Physiology, 29, 13291339. http://dx.doi.org/10.1093/treephys/tpp075

[80] Morelli, T.N. and Carr, S.C. (2011) Review of the Potential Effects of Climate Change on Quaking Aspen (Populus tremuloides) in the Western United States and a New Tool for Surveying Aspen Decline. Report USDA Forest Service Pacific Southwest Research Station, General Technical Report PSW-GTR-235. 
[81] Rohde, A., Bastien, C. and Boerjan, W. (2011) Temperature Signals Contribute to the Timing of Photoperiodic Growth Cessation and Bud Set in Poplar. Tree Physiology, 31, 472-482. http://dx.doi.org/10.1093/treephys/tpr038

[82] Zalesny, R.S., Hall, R.B., Zalesny, J.A., McMahon, B.J., Berguson, W.E. and Stanosz, G.R. (2009) Biomass and Genotype $\times$ Environment Interactions of Populus Energy Crops in the Midwestern United States. Bioenergy Research, 2, 106-122. http://dx.doi.org/10.1007/s12155-009-9039-9 
Scientific Research Publishing (SCIRP) is one of the largest Open Access journal publishers. It is currently publishing more than 200 open access, online, peer-reviewed journals covering a wide range of academic disciplines. SCIRP serves the worldwide academic communities and contributes to the progress and application of science with its publication.

Other selected journals from SCIRP are listed as below. Submit your manuscript to us via either submit@scirp.org or Online Submission Portal.
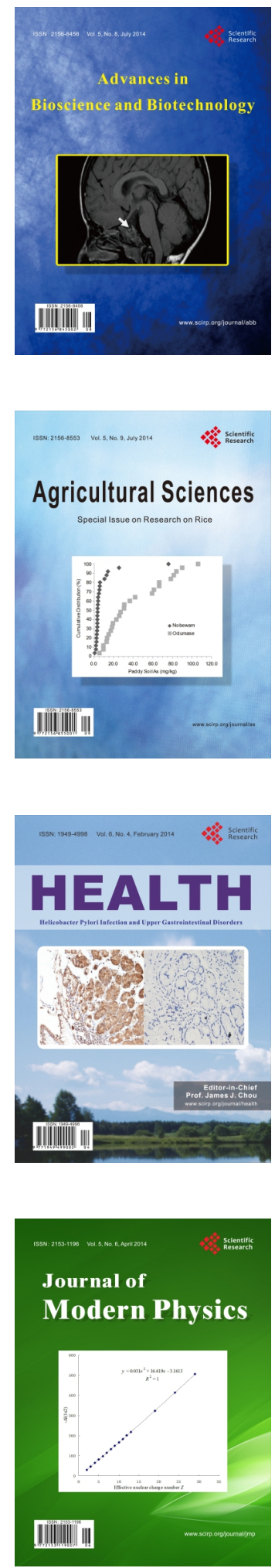
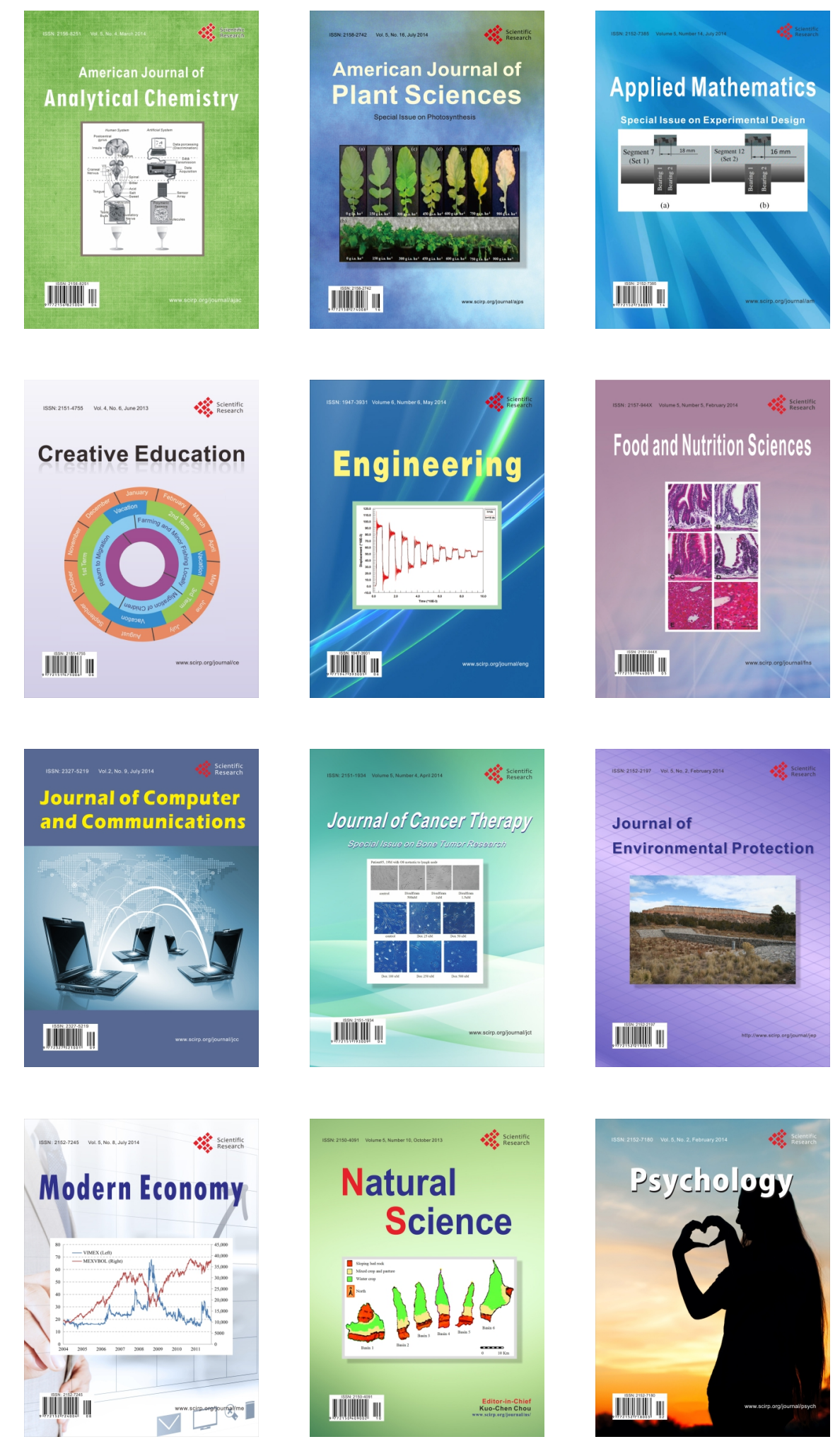